\title{
GENETICAL IMPROVEMENT FOR ALLELOPATHIC ACTIVITY IN SOME RICE GENOTYPES
}

\author{
El-Denary, Medhat E. ; Abd El -Salam Ebeid Draz, Samar .A. \\ Omar. $^{3}$ and Neama El-kholly ${ }^{3}$ \\ 1- Department of Genetics, Faculty of Agriculture, Tanta \\ University.2- Rice Research and Training Center, Sakha, Kafr El- \\ Sheikh, Egypt.
}

\begin{abstract}
The present investigation was conducted at Rice Research and Training Center (RRTC), Sakha, Kafr El-Sheikh, and Laboratory of Genetics Department, Faculty of Agriculture, Tanta University, Egypt. during the three successive rice growing seasons; 2012, 2013 and 2014. Two rice varieties; SK103 and Rikuto Norin 22 as a parents of the running study and their $F_{3}, F_{4}$ and $\mathrm{F}_{5}$ were evaluated against the Echinochloa crus -galli ( barnyard grass)under natural infestation. The results showed that, these varieties showed biologically active suppression of E.crus-galli under field conditions were values ranged from 2.33 to $12.6 \mathrm{~cm}$ for radial area and from 41.33 to $87 \%$ of weed control. The selected genotypes are important and suitable for direct seeded rice, also it could be utilized in the breeding programs to transfer allelopathic activity for commercial varieties to suppress weeds and lowering pollution. The genetic coefficient of variability refers to genotypic effect which played an important role in the inheritance of all studied traits were the heritability in broad sense ranged from 98.06 to 99.98 for allelopathic activity. Two of the ten tested SSR markers (Table 1); RM439 and RM164 showed polymorphic DNA pattern were the primer RM164 exhibited the band with molecular weight $296 \mathrm{bp}$ in all genotypes had strong to allelopathic activity and it was absent in poor rice variety. The SSR markers would be helpful and may identify important of DNA sequencing that help in breeding program.
\end{abstract}

\section{INTRODUCTION}

Rice (Oryza sativa L.) is one of the most important cereal crops in all over the world. In Egypt, it is one of the major cereal crops. The common annual cultivated area of rice crop is about 1.35 million feddans, produced about 5.3 million tons of paddy rice with an average of 4.15 $\mathrm{t} / \mathrm{fed}$, which was considered one of the highest average yield in the world (RRTC, 2016). Rice productivity has remarkably increased year after year according to the percentage replacement of the rice area with the modern varieties to realize a maximum yield average (10tha-1) in the year 2014 against (5.7tha-1) for the period of 1986-1998, because of adopting of the new short duration rice varieties, about $30 \%$ of the irrigation water consumption was saved every year (Aidy and Maximos, 2006). However, the weeds grown in rice fields are the main suppressor of rice growth and significantly affecting rice grain yield. Also the chemical treatments or 
herbicides for weed control are very dangerous due to the pollution and high production costs. Allelopathy is the result of biochemical interactions between plants and represents an economic way to control weeds in rice fields. It is caused by toxic chemicals released by the plant through volatilization, leaching, and root exudation or produced during decomposition of plant residues in the soil (Chou,1995). Success of breeding programs depends on the magnitude of genetic variability and the extent to which the advantageous characteristics are heritable (Mruthunjaya and Mahade 1993). Therefore, the study of genetic variability in rice is not only essential for selecting valuable genotypes and predicting the effect of selecting best genotypes but it will also aid breeders in simultaneous improvement of characteristics through selection (Patil et al., 1993). The aims of this investigation were to study the inheritance of allelopathic activity, some morphological, yield and its components traits through early generations, of some rice genotypes, Haul Sutrex and Necmi. Beser (2005), indicated that selections for grain weight and number of grains per panicle were effective in early generations. The study revealed that the ability of SSR markers to detect and to identify the allelic diversity and genetic variation among the studies rice genotypes.

\section{MATRIALS AND METHODS}

One hundred lines produced from the cross between Two rice varieties (Oryza sativa.) SK103 and Rikuto Norin 22 of the proves study to screaning against the Echinochloa crus -galli ( barnyard grass). The experiments were conducted at the Experimental Farm of the Rice Research and Training Center (RRTC), Sakha, Kafr EL-Sheikh, Egypt, and Laboratory of Genetics Department, Faculty of Agriculture, Tanta University, Egypt. during the three successive rice growing seasons; 2012, 2013, and 2014 throught F3, F4 and F5 generation. All genotypes were evaluated under natural infestation of weeds without using chemical control to determine the allelopathic activity by using the radial area and weed control \% around each individual rice plant of the F3, F4 and F5 generation with their parents which sown in the nursery during the last week of May for each season and transplanted after 30 days at a spacing of $20 \times 20 \mathrm{~cm}$, with three replications in randomized complete block design, the remain cultural practice were applied as recommended by RRTC (2011), data were recorded on morphological and yield characters as, days to heading (day), seed set (\%), grain yield plant-1 and harvest index \%.

Molecular analysis ; Ten SSR markers (RM164, RM439, RM323, RM563, RM413, RM407, RM440, RM262, PAL and P450) were selected from rice data base according to Jensen .et al (2008) used to detect genetic variability under the molecular level among rice 
genotypes under study.Genomic DNA was isolated from $0.5 \mathrm{~g}$ of three weeks old leaves of the used twelve rice genotypes and only ten extremely lines were strong allelopathic activity from the cross (SK103 / Rikuto Norin 22 and their parents (Sakha103 and Rikuto Norin 22), according to (Murray and Thompson, 1980). The quantification and qualification of the extracted DNA was determined on $0.8 \%$ agarose gel comparing to known concentrations of $\lambda$ uncut genomic DNA. The concentration of DNA was adjusted to approximately $15 \mathrm{ng} / \mu \mathrm{l}$ for PCR reaction.

Ten SSR primers were used for studying association allelopathic activity, PCR amplification reactions were done in $25 \mu \mathrm{l}$ reaction mixtures, containing $1 \mu \mathrm{l}$ of DNA template, $2.0 \mu \mathrm{l}$ of each forward and reverse primer, $12.0 \mu \mathrm{l}$ of PCR master mix (Ferments) and $10 \mu \mathrm{l}$ $\mathrm{ddH}_{2} \mathrm{O}$. Thermal cycler was used with the following PCR profile: $95{ }^{\circ} \mathrm{C}$ for $5 \mathrm{~min}$ (initial denaturation step) 35 cycles for of extension, $94^{\circ} \mathrm{C}$ for $1 \mathrm{~min}, 55^{\circ} \mathrm{C}$ for $1 \mathrm{~min}$ (primer annealing), primer elongation at $72^{\circ} \mathrm{C}$ for $2 \mathrm{~min}$ and $72^{\circ} \mathrm{C}$ for $7 \mathrm{~min}$ and stored the last temperature was $4^{\circ} \mathrm{C}$.Ten microliters of PCR amplified product were loaded into $1.8 \%$ agarose gel supplemented with ethidium bromide. The TAE buffer $1 \mathrm{X}$ was used as a running buffer and 50bp DNA ladder was used to estimate the molecular size of the amplified fragments. Electrophoresis was conducted at 60 Volts for $3 \mathrm{~h}$. Gels were then visualized and photographed using Biometra gel documentation unit (BioDoc, Biometra, Germany).

Table (1) list of SSR primer

\begin{tabular}{|l||l||l||l|}
\hline $\begin{array}{l}\text { Locus } \\
\text { Name }\end{array}$ & $\begin{array}{l}\text { Prim } \\
\text { er } \\
\text { Nam } \\
\text { e }\end{array}$ & Forward Primer & \\
& $\begin{array}{l}\text { Reverse Primer } \\
\text { RM1 } \\
\text { RM164 }\end{array}$ & $\begin{array}{l}\text { TCTTGCCCGTCACTGCA } \\
\text { GATATCC }\end{array}$ & $\begin{array}{l}\text { GCAGCCCTAATGCTACA } \\
\text { ATTCTTC }\end{array}$ \\
\hline \hline RM439 & $\begin{array}{l}\text { RM4 } \\
39\end{array}$ & $\begin{array}{l}\text { TCATAACAGTCCACTCC } \\
\text { CCC }\end{array}$ & $\begin{array}{l}\text { TGGTACTCCATCATCCCA } \\
\text { TG }\end{array}$ \\
\hline
\end{tabular}

\section{Statistical Analysis:-}

The data were subjected to analysis of variance for randomized complete block design as suggested by Panse and Sukhatme (1954).

\section{RESULTS AND DISCUSSION}

Mean performance values of one hundred individual plants for each generation (F3, F4 and F5) were presented in Table (2) .

For radial area, the results showed that, highly differences were found among the populations for each generation during the three 
summer seasons. The data on F3 generation showed wide rang between the stronger line and poor line as shown in Table (2) whereas the strong line recorded the highest value $(12.66 \mathrm{~cm})$ of radial area comparing to strong allelopathy rice variety $(9.33) \mathrm{cm}$, that meaning, transgressive segregation was found among the F3 lines as well as, the general mean value was $9.33 \mathrm{~cm}$ that meaning the selection was directed to strong allelopathy, so, the selected population were nearest to the general mean value. The same trend for the allelopathic activity was obtained from F4 and F5 generations and the selection was directed to strong allelopathy, whereas, the general mean values were $9.50 \mathrm{~cm}$ and $10.66 \mathrm{~cm}$ recorded for the F4 and F5 lines, respectively in their allelopathic reaction against weeds ( $E$. crus -galli).

For weed control \%, the results showed that, highly differences were found among the rice genotypes under study whereas, the weed control $\%$ values were ranged between, $41.00 \%$ of poor allelopathic activity to $85.00 \%$ for the strong allelopathic activity in F3 generation, more over, the selected line recorded the highest values 75.00, 74.50 and $74.66 \%$ respectively, indicating to the direction of dominance was towards to better parent. In F4 and F5 generation the general mean values were 80.33 and $82.50 \%$ indicate to the direction of selection was towards the highest values, moreover the values for selected lines of F4 and F5 were nearest to the general mean value, these results were confirmed with the radial area character that meaning, could be develop new promising lines performed as strong to allelopathic activity.

Table (2) Mean performance of parental lines with their selected progenies in F3, F4 and F5 generations for SK 103X Rikuto Norin22 for some morphological characters during 2012, 2013 and 2014 seasons

\begin{tabular}{|c|c|c|c|c|c|c|c|c|}
\hline \multicolumn{2}{|c|}{ Season } & $\begin{array}{c}\text { Entries } \\
\text { SK 103X }\end{array}$ & $\begin{array}{l}\text { line } \\
\text { No. }\end{array}$ & $\begin{array}{l}\text { Radial } \\
\text { Area }\end{array}$ & $\begin{array}{l}\text { line } \\
\text { No. }\end{array}$ & $\begin{array}{c}\text { Weed } \\
\text { control \% }\end{array}$ & $\begin{array}{l}\text { line } \\
\text { No. }\end{array}$ & $\begin{array}{l}\text { Day to Heading } \\
\text { (day) }\end{array}$ \\
\hline \multirow{8}{*}{ กั } & \multirow{8}{*}{ 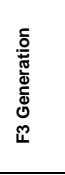 } & P1 & --- & 2.33 & $-\ldots$ & 41.33 & -- & 90 \\
\hline & & P2 & $\cdots$ & 9.33 & $\cdots$ & 87.00 & -- & 93 \\
\hline & & $\mathrm{H}$ & 3 & 12.66 & 3 & 85.00 & 17 & 103 \\
\hline & & $\mathrm{L}$ & 11 & 6.85 & 20 & 41.00 & 85 & 96 \\
\hline & & $\mathrm{S}_{1}$ & 33 & 9.33 & 33 & 75.00 & 33 & 101 \\
\hline & & $\mathrm{S}_{2}$ & 40 & 9.50 & 45 & 74.50 & 70 & 101 \\
\hline & & $S_{3}$ & 51 & 9.33 & 51 & 74.66 & 83 & 102 \\
\hline & & $\mathbf{X}$ & $-\cdots$ & 9.33 & --- & 75.33 & $-\ldots$ & 101 \\
\hline \multirow{8}{*}{ ลั } & \multirow{8}{*}{ 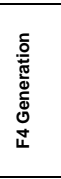 } & P1 & $-\cdots$ & 2.66 & $-\ldots$ & 38.66 & $-\ldots$ & 91 \\
\hline & & P2 & $\cdots$ & 9.33 & $\cdots$ & 85.33 & -- & 95 \\
\hline & & $\mathrm{H}$ & 20 & 12.66 & 20 & 88.00 & 20 & 102 \\
\hline & & $\mathrm{L}$ & 17 & 6.40 & 17 & 45.00 & 35 & 97 \\
\hline & & $\mathbf{S}_{1}$ & 35 & 9.66 & 33 & 78.00 & 35 & 100 \\
\hline & & $\mathbf{S}_{2}$ & 62 & 9.33 & 62 & 78.33 & 42 & 100 \\
\hline & & $\mathbf{S}_{3}$ & 81 & 9.33 & 81 & 80.66 & 81 & 100 \\
\hline & & $\mathrm{X}$ & $-\cdots$ & 9.50 & -- & 80.33 & $\cdots$ & 100 \\
\hline \multirow{8}{*}{ ฉั } & \multirow{8}{*}{ 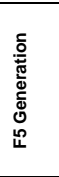 } & P1 & $-\cdots$ & 3.24 & -- & 40.00 & --- & 91 \\
\hline & & P2 & -- & 10.50 & -- & 89.00 & 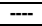 & 93 \\
\hline & & $\mathrm{H}$ & 51 & 12.33 & 51 & 88.66 & 80 & 102 \\
\hline & & $\mathrm{L}$ & 38 & 5.21 & 80 & 46.00 & 62 & 98 \\
\hline & & $\mathbf{S}_{1}$ & 16 & 10.13 & 16 & 80.00 & 17 & 100 \\
\hline & & $\mathbf{S}_{2}$ & 72 & 10.33 & 72 & 81.00 & 72 & 100 \\
\hline & & $S_{3}$ & 95 & 10.33 & 63 & 79.00 & 89 & 100 \\
\hline & & $\mathbf{X}$ & $\cdots$ & 10.66 & $\ldots$ & 82.50 & $\cdots$ & 100 \\
\hline
\end{tabular}

$\mathrm{H}$ : The highest value

$\mathrm{L}$ : The lowest value

$\mathrm{S}:$ The selected lines 
For days to heading, narrow differences for days to heading was found for the parental lines, because the two parents were early in heading date, while the produced populations were late for heading date, whereas the selection for this trait was direct to the plants which recorded the lowest days to heading indicating to could be utilize from these populations as donors to transfer these desirable characteristics thought breeding programs. Similar results were obtained for most studied traits by El-Abd and Abdalla (2004); Babu et al.,(2006) hammoud,(2005).

Mean performance values of the hybrid combination SK.103 / Rikuto Norin 22 with their parents through F3, F4 and F5 generation for some yield and its components characters during three summer seasons 2012,2013 and 2014 are shown in Table (3).

For seed set \%, as shown in Table (3) narrow differences of seed set \% was found among the parental lines with their progenies for the hybrid combination SK. 103 / Rikuto Norin 22, whereas, the SK 103 recorded $86 \%$ but, the Rikuto Norin 22 recorded $90 \%$ during 2012 season .

Table (3) Mean performance values of the populations produced from the F3,

F4 and F5 generation for SK 103X Rikuto Norin22 hybrid and its parents for some yield and its component characters during 2012, 2013and 2014seasons

\begin{tabular}{|c|c|c|c|c|c|c|c|c|}
\hline \multicolumn{2}{|c|}{ Season } & \multirow{2}{*}{$\begin{array}{c}\text { Entries } \\
\text { SK 103X } \\
\text { Rikuto } \\
\text { Norin22 } \\
\text { P1 }\end{array}$} & \multirow{2}{*}{$\begin{array}{l}\text { line } \\
\text { No. } \\
--- \\
\end{array}$} & \multirow{2}{*}{$\begin{array}{c}\begin{array}{c}\text { Seed set } \\
(\%)\end{array} \\
\\
86\end{array}$} & \multirow{2}{*}{$\begin{array}{c}\text { Line No. } \\
---\end{array}$} & \multirow{2}{*}{$\begin{array}{c}\text { Harvest } \\
\text { index } \%\end{array}$} & \multirow{2}{*}{$\begin{array}{l}\text { line } \\
\text { No. } \\
--- \\
\end{array}$} & \multirow{2}{*}{$\begin{array}{c}\begin{array}{c}\text { Grain yield } \\
\text { /plant } \\
\text { (gm) }\end{array} \\
\mathbf{2 8 . 6 6}\end{array}$} \\
\hline \multirow{8}{*}{ ำ } & \multirow{8}{*}{ 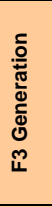 } & & & & & & & \\
\hline & & P2 & $---\cdot$ & 90 & --- & 47.50 & --- & 49.33 \\
\hline & & H & 11 & 100 & 3 & 61.33 & 3 & 95 \\
\hline & & $\mathbf{L}$ & 18 & 80 & 18 & 32.50 & 18 & 60 \\
\hline & & $\mathrm{S}_{1}$ & 33 & 95.33 & 33 & 39.50 & 33 & 70 \\
\hline & & $\mathrm{S}_{2}$ & 40 & 95.66 & 40 & 40.33 & 40 & 70.33 \\
\hline & & $\mathrm{S}_{3}$ & 100 & 95.33 & 100 & 40.33 & 90 & 70.66 \\
\hline & & $\mathbf{X}^{-}$ & -- & 95 & ---- & 40.23 & -- & 70.33 \\
\hline \multirow{8}{*}{ ণ } & \multirow{8}{*}{ 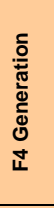 } & P1 & ---- & 83 & --- & 39.50 & ---- & 30.33 \\
\hline & & P2 & ---- & 92 & $-\cdots$ & 45.23 & ---- & 57.50 \\
\hline & & $\mathbf{H}$ & 20 & 100 & 20 & 63.33 & 20 & 99.80 \\
\hline & & $\mathbf{L}$ & 70 & 85 & 17 & 31.50 & 17 & 53 \\
\hline & & $S_{1}$ & 35 & 95.50 & 35 & 45.50 & 35 & 75 \\
\hline & & $\mathrm{S}_{2}$ & 51 & 95.33 & 51 & 45.66 & 62 & 75.33 \\
\hline & & $\mathrm{S}_{3}$ & 59 & 95.11 & 65 & 44.33 & 65 & 75.66 \\
\hline & & $x^{-}$ & --- & 95.33 & --- & 45.50 & ---- & 75 \\
\hline \multirow{8}{*}{$\frac{⿱}{\circ}$} & \multirow{8}{*}{ 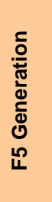 } & P1 & --- & 88 & --- & 40.33 & --- & 27.50 \\
\hline & & P2 & $-\cdots$ & 93 & --- & 45.33 & --- & 52.33 \\
\hline & & $\mathbf{H}$ & 31 & 100 & 51 & 64.23 & 51 & 112 \\
\hline & & $\mathbf{L}$ & 18 & 82 & 40 & 37.33 & 40 & 45 \\
\hline & & $S_{1}$ & 16 & 95.33 & 16 & 49.50 & 16 & 80.50 \\
\hline & & $\mathrm{S}_{2}$ & 60 & 96.27 & 60 & 50.33 & 72 & 81.66 \\
\hline & & $\mathrm{S}_{3}$ & 80 & 96.33 & 98 & 50.33 & 80 & 81.33 \\
\hline & & $\mathbf{X}^{-}$ & --- & 96.33 & -- & 50.00 & --- & 81.86 \\
\hline
\end{tabular}

P1: The first parent

$\mathrm{H}$ : The highest value
$\mathrm{L}$ : The lowest value
P2: The second parent

$\mathrm{S}$ : The selected lines

On the other hand, wide differences of seed set \% was found among all these progenies, the highest value was $100 \%$ of line No (11) and lowest value was $80 \%$ of line No (18) , but, general mean 
value was $95 \%$ and selected populations recorded the same value , the results indicate the direction of selection was towards the dominant value and the genetic improvement was $5 \%$ surpassed the better parent, the same trend of results were found in the F4 and F5 generations, whereas the general mean value were 95.33 and 96.33 respectively, during both 2013 and 2014 seasons respectively. That meaning, the direction of selection was toward the highest value, and could be enable the breeders to develop a new promising lines with highest allelopathic activity, seed set $\%$ and high grain yield. For Harvest index \% as shown in Table (3) wide differences was found among the parental lines with their progenies for the hybrid combination of SK103 / Rikuto Norin 22, whereas, the highest Parent (Rikuto Norin22) recorded value $47.50 \%$ but, the lowest (SK 103) parent recorded value $42.50 \%$. Moreover, the progeny of F3 generation recorded wide differences of mean performance, the highest line recorded value $61.33 \%$ and the lowest line recorded value $32.50 \%$ while, the general mean value was $40.23 \%$ and the selected populations were recorded the similar values, the results indicate to the direction of selection was toward the highest value of Harvest index $\%$. So, could be develop new promising line with high yielding and strong to allelopathic activity, moreover, the general mean values for F4 and F5 were $45.50 \%$ and $50.00 \%$, respectively, these results, indicate that, the direction of selection was toward the highest value of Harvest index \% for F4 and F5 generation, to develop new promising line high Harvest index \% with strong to allelopathic activity.

For grain yield / plant $(\mathrm{gm})$ as shown in Table (3) wide range of grain yield / plant (gm) was found among the parental lines with their progenies for the hybrid combination SK103 / Rikuto Norin 22, whereas, the highest parent recorded value $49.33 \mathrm{gm}$, but , the lowest parent recorded value $28.66 \mathrm{gm}$. Moreover, the progenies of F3 generation recorded wide rang of mean performance, the highest line recorded value $95 \mathrm{gm}$ / plant and the lowest line recorded value $60 \mathrm{gm}$ / plant, while, the general mean value was $70.33 \mathrm{gm} /$ plant and the selected populations were recorded the similar values, the results indicate to the direction of selection was toward the highest grain yield. So, could be develop new promising line with high yielding and strong to allelopathic activity, moreover, the general mean values for F4 and F5 were 75 and $81.86 \mathrm{gm} /$ plant respectively, these results, indicate, the direction of selection was toward the highest value for grain yield through F4 and F5generation, to develop new promising line with high yielding and strong in allelopathic activity. Same results were obtained for most studied characteristics by Adnan Kanbar et al (2011) who found that, In pedigree method, the mean values of grain yield were higher in F4 (18.62 g), F5 (20.89 g) and F6 (23.47 g) generations. In 
F5generation, Number of tillers and number of panicles were increased from F3 generation to F5 generation.

The data in Table ( 4 ) showed highly differences and significant for the studied characters, the mean square values and heritability in broad sense of one hundred populations for each; F3, F4 and F5 of the hybrid combination Sakha $103 \mathbf{X}$ Rikuto Norin22 for some morphological characters, Radial area, weed control \% and days to heading recorded the highest values during 2012, 2013 and 2014 seasons, indicating that these characters were under genetic control and no influences by environmental conditions.

Table (4) Mean square values of the selected genotypes for F3, F4 and F5 for SK 103X Rikuto Norin22 hybrid for some morphological characters during 2012, 2013 and 2014seasons

\begin{tabular}{|c|c|c|c|c|c|c|c|c|c|c|}
\hline \multirow{2}{*}{ S.O.V } & \multirow{2}{*}{ d.f } & \multicolumn{3}{|c|}{ Radial area $(\mathrm{cm})$} & \multicolumn{3}{|c|}{ Weed control \% } & \multicolumn{3}{|c|}{ Day to heading (days) } \\
\hline & & 2012 & 2013 & 2014 & 2012 & 2013 & 2014 & 2012 & 2013 & 2014 \\
\hline Reps. & 2 & 0.012 & 0.009 & 0.001 & 0.06 & 0.13 & 0.011 & 0.023 & 0.04 & 0.003 \\
\hline Population & 99 & $21.57^{\star \star}$ & $26.45^{\star \star}$ & $19.79^{\star \star}$ & $289.53^{\star \star}$ & $236.35^{\star \star}$ & $311.55^{\star \star}$ & $85.94^{\star \star}$ & $101.18^{\star \star}$ & $67.36^{\star *}$ \\
\hline Error & 198 & 0.23 & 0.28 & 0.39 & 0.26 & 0.03 & 0.70 & 1.56 & 2.74 & 1.49 \\
\hline H.b.s & & 98.95 & 98.95 & 98.06 & 99.91 & 99.98 & 99.77 & 98.21 & 97.36 & 97.83 \\
\hline $\mathbf{S}$ & & 4.64 & 5.14 & 4.44 & 17.01 & 15.37 & 17.65 & 9.27 & 10.06 & 8.21 \\
\hline C.V & & 0.024 & 0.029 & 0.036 & 0.003 & 0.001 & 0.008 & 0.015 & 0.027 & 0.015 \\
\hline
\end{tabular}

The data in Table (5) showed the mean square values of one hundred individual plants of each genotypes for F3, F4 and F5 of the hybrid combination of Sakha 103 X Rikuto Norin22 for some yield and its component characters, seed set \%, Harvest index \% and grain yield / plant $^{-1}$ during 2012, 2013 and 2014 seasons. The mean square values for the genotypes were highly significant of all selected lines from all generations and the selection will be effective to get promising line with desirable characters, This mean that, all these characters were under genetic control, in the same time, the heritability in broadsence were more than $90 \%$ for all the characters of the three generations, this referred to genetic stability of F4 and F5 generations, finally, the variance and coefficient of variation showed that the studied characters did not affected by the environmental factors. Same results were previously obtained by Han et al., (1995); Hammoud et al., (2012) and El-Malky et al., (2013), they found that, moderate genetic advance along with high heritability indicating the involvement of additive type of gene action in controlling these characters. 
Table (5) Mean square values of the selected genotypes for F3, F4 and F5 for SK 103X Rikuto Norin22 hybrid for some yield and its component characters during 2012, 2013 and 2014 seasons

\begin{tabular}{|c|c|c|c|c|c|c|c|c|c|c|}
\hline \multirow{2}{*}{ S.O.V } & \multirow{2}{*}{ d.f } & \multicolumn{3}{|c|}{ Seed set $\%$} & \multicolumn{3}{|c|}{ Harvest index\% } & \multicolumn{2}{|c|}{ 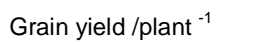 } & \multirow[b]{2}{*}{2014} \\
\hline & & 2012 & 2013 & 2014 & 2012 & 2013 & 2014 & 2012 & 2013 & \\
\hline Reps. & 2 & 0.011 & 0.014 & 0.026 & 0.021 & 0.0131 & 0.003 & 0.015 & 0.003 & 0.004 \\
\hline Population & 99 & $840.55^{\star \star}$ & $798.30^{* *}$ & $703.32^{\star *}$ & $145.62^{* *}$ & 178.30 ** & $170.50^{* *}$ & $1301.80^{* *}$ & $1142.11^{\text {** }}$ & $1171.93^{* *}$ \\
\hline Error & 198 & 2.23 & 1.58 & 1.12 & 1.22 & 1.03 & 0.89 & 5.38 & 2.83 & 3.74 \\
\hline H.b.s & & 99.73 & 99.80 & 99.84 & 99.17 & 98.07 & 99.42 & 99.58 & 99.75 & 99.68 \\
\hline S & & 28.99 & 28.25 & 26.52 & 12.07 & 13.35 & 13.06 & 36.08 & 33.79 & 34.23 \\
\hline C.V & & 0.023 & 0.016 & 0.012 & 0.030 & 0.023 & 0.018 & 0.076 & 0.038 & 0.046 \\
\hline
\end{tabular}

There were positive and significant associations between grain yield and allelopathic activity in all populations in three years. High heritabilities were estimated for most studies characteres, heritability values showed that grain yield weight as well as allelopathic activity traits could be used as selection criterion in early generations.

\section{Molecular analysis}

Ten SSR markers were used in this study to analyse genetic variability at molecular level among the studies rice genotypes. Among ten SSR markers only two primers generated polymorphic alleles (RM164 and RM439) while, eight markers (RM323, RM563, RM413, RM407, RM440, RM262, PAL and P450) showed monomorphic allele with all studied genotypes. The detected polymorphism reflects the amount of diversity among the tested genotypes and thus the possibility of genetic improvement for such a set of genotypes could by using in breeding programs since genetic diversity is the prerequisite for successful such programs.

The banding patterns presented in Figures (1 and 2) and Table (6). The obtained results showed clear polymorphism between the two parents Sakha103 and RikutoNorin22 with their respective $F_{5}$ populations. Two primers, RM164 and RM439 were be have the point to the strong or poor allelopathy. Hence, the two primers were used to screen the individual components of strong and poor along with their parents.

Figure (1) showed that the primer RM164 demonstrated polymorphic bands (alleles) with size of $296 \mathrm{bp}$ for strong parent (Rikuto Norin22) and ten selected lines strong to allelopathic activity of $\mathrm{F}_{5}$ lines resulting from the cross sakha103 (P1) x Rikuto Norin22 (P2) while, the band with the size of $254 \mathrm{bp}$ was presented in the poor parent sakha103, these results showed that the primer RM164 was found to be segregating with strong and poor individuals in a codominant fashion and indicating to the band296 bp of the primer RM164 may be related to activity to allelopathy while, the band $254 \mathrm{bp}$ 
of the same primer may be related to suppress to allelopathy as shown in Table (2)

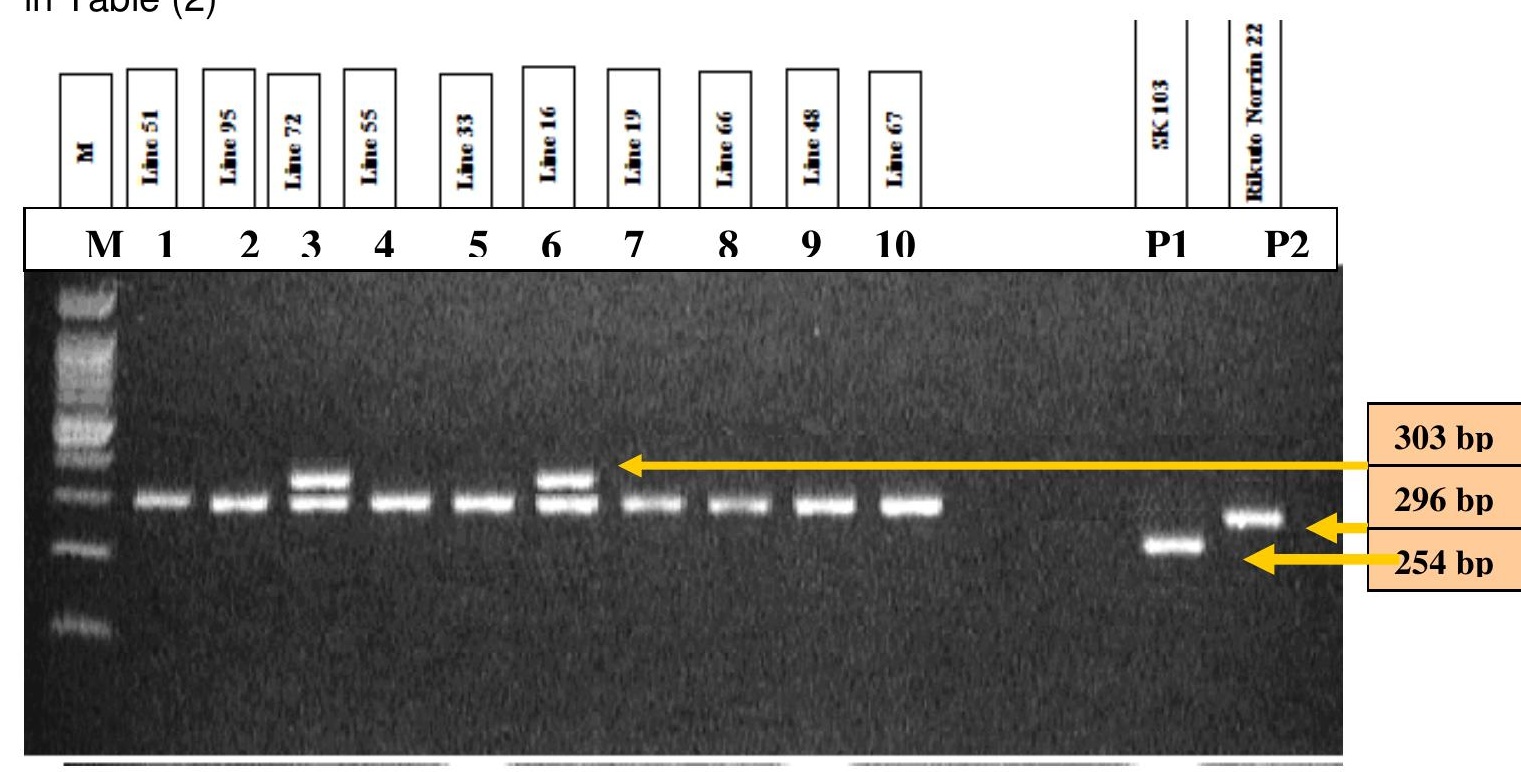

Fig. (1) Agarose gel electrophoresis of PCR productof the ten selected lines, lane 1 to lane 10, P1 is Sakha103,P2 is Rikuto Norin 22 and $M$ is 100 bp DN Aladder

Lanes 1-10 are ten selected lines of F5 generation according allelopathy activity and yield components. Comparing with both parents, all selected lines showed the associated band with allelopathy activity $296 \mathrm{bp}$, while the band $254 \mathrm{bp}$ was presented in the parent sk103 and absent in selected lines, indicating to the selection were for allelopathy during F2, F3 and F4. On the other hand, a new allele (303 bp) appear in some lines; lane 3 and 6 , this band may be related to highest grain yield as shown in Table (3).

The conducted DNA banding pattern RM 439 primer showed in Figure (2) polymorphic alleles among all studied genotypes, Rikuto Norin 22 and Sk103 with their F5 generation, strong parent Rikuto Norin 22 showed one distinguish band with molecular mass 576 bp with six lines of F5 generation which was absent in four lines and poor parent Sk103. Primer RM439 gave also an other distinguish band (131 bp) in the parent SK103 and two line; lane 5and 9. 


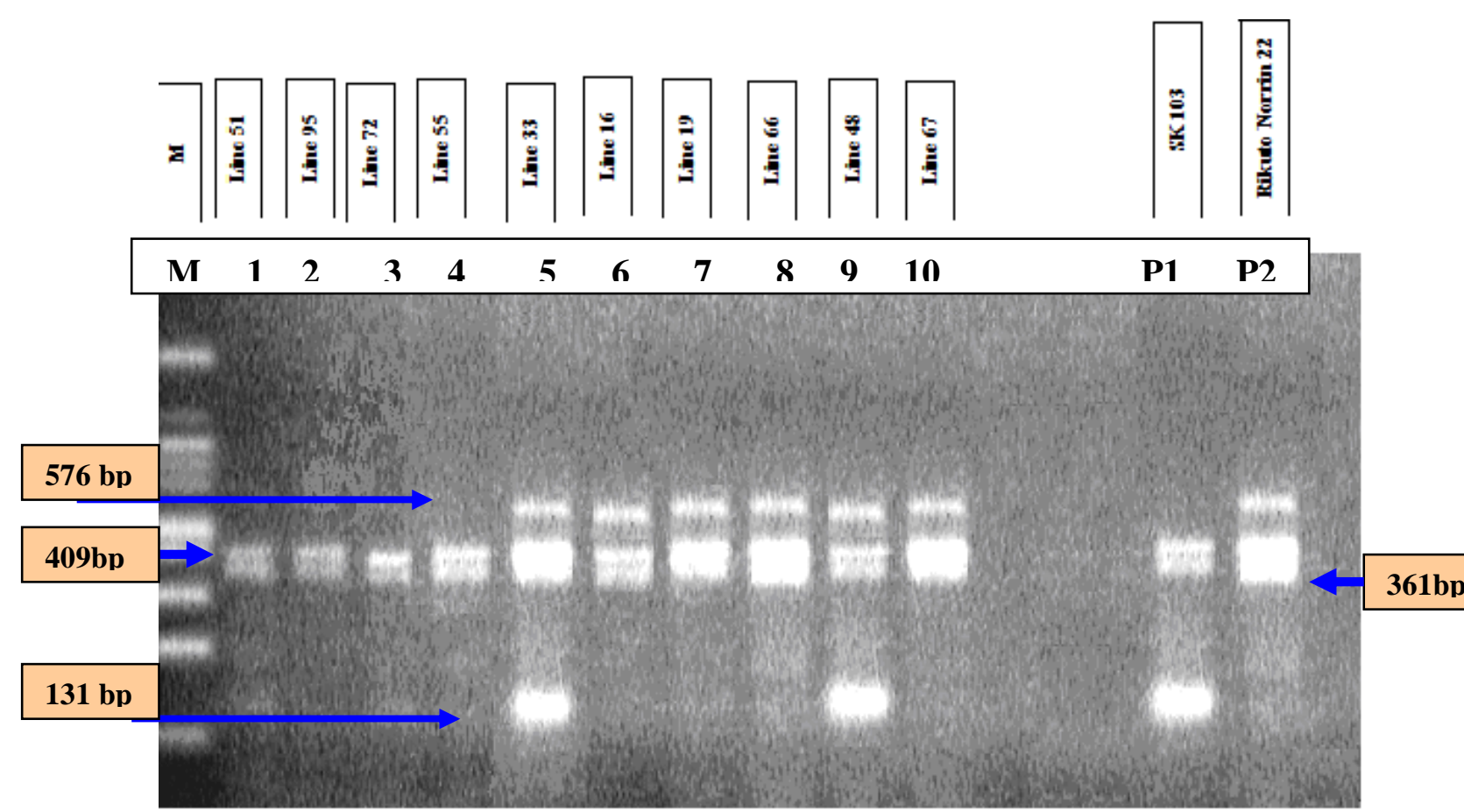

Fig. (2) Agarose gel electrophoresis of PCR productof the ten selected lines, lane1 to lane 10, P1 is Sakha103, P2 is Rikuto norin22and $M$ is 100 bp DNA ladder.

Table 6. Showed presence and absence matrix

\begin{tabular}{|l|l|l|l|l|l|l|l|l|l|l|l|l|l|l|}
\hline Marker & alleles & P1 & P2 & 1 & 2 & 3 & 4 & 5 & 6 & 7 & 8 & 9 & 10 & M.W \\
\hline RM164 & 1 & 0 & 0 & 0 & 0 & 1 & 0 & 0 & 1 & 0 & 0 & 0 & 0 & 303 \\
\hline & 2 & 0 & 1 & 1 & 1 & 1 & 1 & 1 & 1 & 1 & 1 & 1 & 1 & 296 \\
\hline & 10 \\
\hline
\end{tabular}

\section{CONCLUSION}

In conclusion, this study indicated that presence of genetic diversity among the mean performance of all generations for all studied traits. The genotypic effect was significant in allelopathic activity traits (radial area andweed control \%) indicated that genotypic effect played an important role in determining the inheritance of these traits. Our finding with the SSR markers tested pointed to some distingush vans (alleles) and cauld be used as selection tool in early generation. the results, could be concluded also that, the parent Rikuto 
Norin 22 recorded a wide radial area and mean values of grain yield, finally, line No.16 and line No.72 for the cross Sakha 103 / Rikuto Norin 22 which similer to their male parent with reaction to the two primer RM164 and RM439 and might be considered as the most superior and prospective genetic materials for most studied characters, especially had the wide radial area to weed control and highest yield / plant.

\section{REFERENCES}

Adnan Kanbar; K. Katsuhiko and H.E. Shashidhar (2011). comparative efficiency of pedigree, modified bulk and single seed descent breeding methods of selection for developing high-yielding lines in rice (Oryza sativa L.) under aerobic condition. Journal of Plant Breeding, 2(2):184-193

Aidy, I. R. and M. A. Maximos (2006). Rice varietal improvement in Egypt during the last two decades: achievements and future strategies. Egypt, J. Agric. Res., 83(5A): 23-30.

Babu, V. R.; S. Kishore; N. Shobha Rani and Ravichandran (2006). Genetic divergence analysis using quality traits in rice genotypes (Oryza sativa L.). Oryza, 43 (4): 260-263.

Chou, C.H. (1995). Allelopathic compounds as naturally occurring herbicides. Proceedings of the 15th Asian-Pacific Weeds Control Conference, Tsukuba, Japan, pp. 154-15

El-Abd, A. B. and A. A. Abd Allah (2004). Genetic behavior of some grain quality characters in rice (Oryza sativa L.). Egyptian Journal of Agricultural Research, 82(1): 167-182.

El-Malky, M.M.; M.M. El-Habashy; S.A.A. Hammoud and M.R. Shreif (2013). Genetic studies of some rice varieties for rice stem borer (Chilo agamemnon Bles.) and agronomic characters under Egyptian condition. Egypt. J. Plant breeding, 17(2): 196-212.

Haul Sutrex and Necmi. Beser (2005).Selection for grain yield \&yield components in early generation for temperate rice. Crop Science Society of the Philippines .

Hammoud, S. A. A. (2005). Genetic behavior of some agronomic characters in two ricecrosses. Egypt. J. Agric. Res. 83(5B):

Hammoud, S.A.A; S.E.M. Sedeek; I.O.A. Rewaniy and R.A. El-Namaky (2012). Genetic behavior of some agronomic traits, blast disease and stem borer resistance in two $\mathrm{N}$ levels. J. Agric. Res., Kafr Elsheikh Egypt, 38(1): 83-105.

Univ.,

Han, Q.L.; P. Zhuang; Z.H. Tang; Q.F. Han; P.J. Zhuang and Z.H. Tang (1995). Estimation of realized heritability of resistance to penetration rice stem borer Chilo suppressalis. Acta. Entomology. Academia Sinca, 38 (4): 402-406, (In Chines).

Jensen. L. B.. ${ }^{*}$, B. Courtois ${ }^{b}$ and M. Olofsdotter ${ }^{c}$ (2008)Quantitative Trait Loci Analysis of Allelopathy in Rice Univ. of Aarhus, Dep. of Genetics and Biotechnology, DK-4200 Slagelse, Denmark 
Mohapatra, K.C. and H.K. Mohanty (2008).Inheritance of some quantitative characters including heterosis in rice by combining ability analysis. Rice Genetics 1: 579-591.

Mruthunjaya, C.W. and M. Mahade (1993). Genetic variability, heritability and genetic advance for yield and its contributing characters in ratoon crop of rice (Oryza sativaL.). Mansore J Agric. Sci., 29: 285288.

Murray, A. A. and W. F. Thompson (1980). Rapid isolation of high molecular weight plant DNA. Nucleic Acid Res. 8: 4321 - 4325

Panse, V.G and P.V. Sukhatme (1954). Statistical Methods for Agricultural Workers. Indian Council of Agric. Res., New Delhi, 227 p.

Patil, P.A.; C.R. Mahajan; S.S. Mehetre and D.N. Hajare (1993). Analysis of variability and heritability in upland rice. Oryza, 30: 154-156.

RRTC (2011). National Rice Research Program: Final results of 2010 growing season. Sakha, Egypt.

RRTC (2016). National Rice Research Program: Final results of 2015 growing season. Sakha, Egypt.

Tang (1995). Estimation of realized heritability of resistance to penetration rice stem borer Chilo suppressalis. Acta. Entomology. Academia Sinca, 38 (4): 402-406, (In Chines).

التحسين الوراثي لنشاط الاليلوباثى في بعض التراكيب الوراثية للأرز

مدحت عراقى الدينارى (1) عبد السلام عبيد دراز (2) سمر عمر (3) نعمه الخولى (3)

(1)قسم الوراثه - جامعه طنطا ـ (2) مركز البحوث والتدريب فى الارز - سخا ـ كفر الثيخ

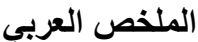

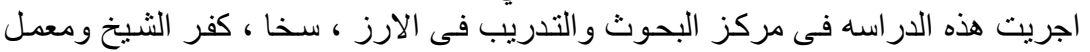

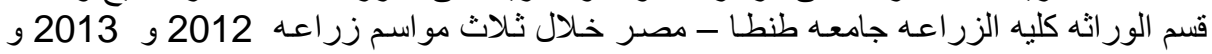

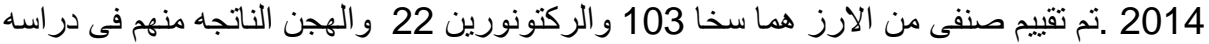

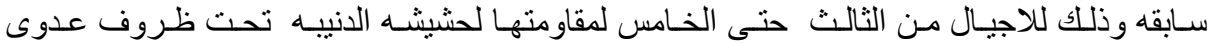

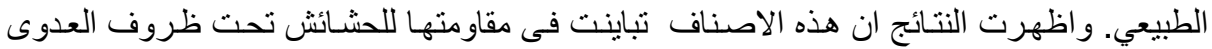

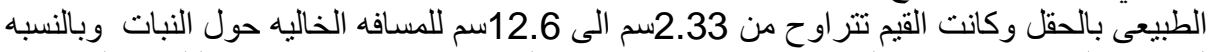

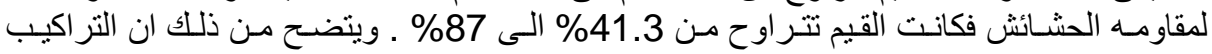

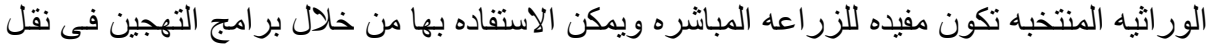

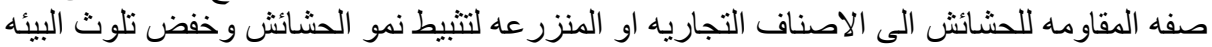

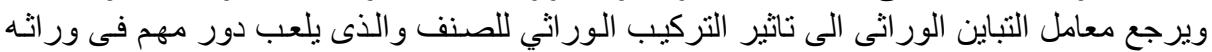

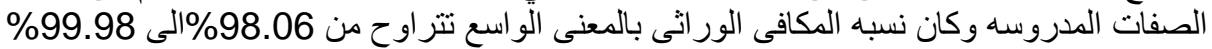

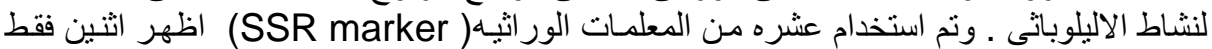

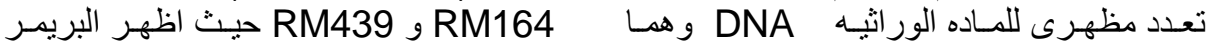

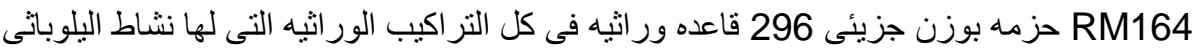

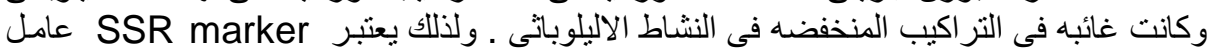

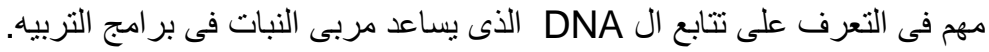

